\title{
HOW DARE YOU? \\ A CRITICAL INCIDENT IN A PORTUGUESE AS A SECOND LANGUAGE CLASSROOM
}

Flávia da Silva Pereira Albuquerque Oliveira é mestranda em Estudos da Linguagem na PUC-RIO e atua como professora convidada no curso intensivo de Português para Estrangeiros na mesma universidade.

E-mail: flaviaspao@gmail.com

\section{Resumo}

Este é um relato de experiência que descreve uma situação ocorrida em uma sala de aula de Português para Estrangeiros. Os alunos encontravam-se no Brasil, mais especificamente na cidade do Rio de Janeiro, e consequentemente aprendiam o português como segunda língua em um ambiente de imersão. Estereótipos positivos e muito frequentemente estereótipos negativos em relação ao Brasil fazem parte da bagagem destes alunos. Este relato diz respeito a minha primeira experiência de ter que lidar com um destes estereótipos negativos: o do Brasil entendido como o país da corrupção e da bagunça. A experiência em si e as reflexões que a sucederam, descritas aqui neste relato, foram extremamente enriquecedoras e significativas para a minha vida profissional e pessoal.

\begin{abstract}
This is a critical incident which describes a situation that took place in a Portuguese for foreigners' classroom. The learners were in Brazil, more specifically in the city of Rio de Janeiro and, consequently, were learning Portuguese as a second language in an immersion environment. Positive stereotypes and very frequently negative stereotypes about Brazil are part of these students' baggage. This critical incident refers to my first experience in having to deal with one of these negative stereotypes: Brazil being understood as the country of corruption and disorder. The experience itself and the following reflections about it, described here in this paper, were extremely enriching and meaningful for both my professional and personal life.
\end{abstract}

My first time teaching Portuguese as a second language yielded me some very interesting experiences and understandings. For many years I had taught English as a foreign language to Brazilians - both children and adults. I also had experience teaching Portuguese as a native language, but teaching Portuguese for foreigners made me, for the first time, look at my own language/culture from a different perspective. Another challenge for me was definitely having to deal with my student's views of my own language/culture. I had a lot to learn.

This first group of students was composed of eight learners, all of them in their early twenties. Among them there was a young German lady, a young Jamaican man called Anthony ${ }^{1}$, a Chinese who was raised in the United States and five Americans coming from different parts of the U.S. My experience with these pupils was enriching and meaningful for my professional life in a very unique way.

Since the very first day they were all very receptive to me and we got along well. They seemed to be engaged and were extremely participative, especially when we talked about cultural matters. Most of them also had a very good sense of humor; every class we would laugh about something funny somebody said or did and, for me, the time we spent together was a lot of fun. There was one student, the Jamaican, who was particularly funny. Sometimes I even had the impression he was trying to show off.

One morning, I had planned to teach them how to use the "futuro do pretérito" and the "imperfeito do subjuntivo", two verb tenses that are recurrently used together in the Portuguese language. They had already seen the "futuro do pretérito" in a previous

\footnotetext{
${ }^{1}$ The name of the student has been modified in order to protect his identity.
} 
class, and I chose to start this lesson with a video taken from a news program, which showed a reporter interviewing people on the streets of Uberlândia, a city in Minas Gerais. The news was about the "Mega Sena da virada" and the reporter explained what this event was, and asked people what they would buy if they won the "Mega Sena da virada" - in Portuguese: "O que você compraria, se você ganhasse na Mega Sena da virada?"

The reporter (narrator) on the video explained that this is a special lottery that happens once a year, on December $31^{\text {st }}$, and that it has the largest prize of all the lotteries from the whole year. This is truly a very well-known event in Brazil, and most of us take a chance and make a bet ("fazer uma fézinha", as we say) to try to win this lottery - even the people that throughout the year are not used to playing the lottery, like myself.

I try to use authentic materials as often as possible in my classes and I believe besides being interesting for the students, they are extremely useful and important in language teaching for many reasons. As Clouet (2006, p. 58) defends, materials should promote discussions, comparisons and reflection on both own and target cultures, including such objects as cultural symbols and products, cultural behavior (what is considered appropriate, values, non-verbal communication), and also for exploring cultural experiences (looking at learners' own feelings and experiences of the target culture). Authentic materials such as this one truly provide us with all these possibilities.

My intention was to introduce the grammar topic through showing them how, in real life, we would use those two verb tenses together. I thought that along with the grammar, the video gave me the chance to work their listening skills, introduce and discuss about a cultural habit - since the lottery is part of the country's culture - and speaking skills, once they would be talking about the subject.

I believed this was an interesting, cultural way to start the lesson and that we would be able to examine the video from the point of view of content, and not merely in the service of language learning. I asked the students about lotteries in their countries, if there was an event similar to "Mega Sena da virada", explained what "virada do ano" was: the turn from one year to the next. We also shared personal experiences and opinions about what we would do if we won all that money.

In addition to that, we had the chance to talk about the different pronunciations and accents in the different parts of a country, about the expressions used by the interviewees, since they were from Uberlândia, and the students noticed that even the intonation changed considerably from cariocas to mineiros.

"Mineiros talking sounds as if they were singing", they said.

Until that moment the lesson was going exactly as I had planned. Everyone was participating and they seemed motivated by the topic.

After all the discussion, understanding of the video, and exchanging of cultural information, I showed them the PPT presentation I had prepared with the systematization of the new grammar topic and sentences taken from the information we had seen on the video, for example: "O que ele faria com o dinheiro da Mega Sena? - 
Ele viajaria pelo mundo." In English: "What would he do with the money? - He would travel around the world".

After I showed them the PPT with the construction of the "imperfeito do subjuntivo" and we came to the conclusion of how it worked with the "futuro do pretérito", I had some questions for them to practice the grammatical structures they had just learned and one of the questions was:

"Se a Polícia Federal do Brasil te impedisse de ficar aqui, o que você faria?", which in English would mean: "If the Brazilian Federal Police did not allow you to stay here, what would you do?"

As I had only eight pupils in class, many times I would listen to all of them. Before anyone else, the Jamaican insolently answered with a slight smile on his face:

"Ah, no Brasil não seria um problema. Eu daria dinheiro para o policial me deixar ficar aqui." Translating it to English, he said: "In Brazil it wouldn't be a problem. I would bribe the policemen and they would let me stay."

I cannot explain how offensive and disrespectful that comment sounded to me at that moment. His attitude and intonation intensified the tone of discourtesy. It seemed he wanted to be funny and even though I believe it was not personal, I felt very much in my right to promptly answer him back:

"I'm sorry, Anthony, but I think you are making a wrong generalization about the Brazilian Police. That's not how things work here. You might have heard of corruption in our country and I'm sure it exists, but I'm also sure there are corrupt people everywhere in the world. So, that means you should not think that way about Brazilians."

When I finished that sentence all I could hear was silence. Anthony did not say anything in response and all the other students looked at me as if they were ashamed for what their peer had just said. I am pretty sure all of them noticed I had been personally offended. We went on with the activity and everyone else gave their own answers. I tried my best to make the rest of the lesson flow naturally, and to act as if nothing was bothering me.

After the class finished I could not stop thinking about what had happened and I had to share it with someone. Juliana, the teacher that took turns with me teaching that group, was going to be the first one to hear. As soon as we met in the teacher's room I said:

"Let me tell you what happened today..." and I vented my resentment. Yes, I was indeed insulted.

I was worried that my vehement reaction could have been inappropriate, but Juliana agreed that I could not leave all the other students thinking that Anthony's opinion was correct and even worse, that I agreed with him. I truly did not.

I went home and could not stop thinking about the situation. I could see it happening over and over again in my mind. I was very much intrigued and puzzled: "What makes him think that way? Why did I take it so personally? Was I too emphatic in my answer? Should I talk to him privately tomorrow? Is he going to understand what I meant? Will the others understand? Even if he thought that, how presumptuous was he 
to have said it! He has just arrived in Brazil... What does he think he knows about us and about how things work here?"

I spent the rest of the day thinking and reflecting. When my husband arrived home I verbalized the situation one more time to him. My mom called me that evening, and I also told her about what had happened and how I was feeling. Everyone seemed to agree that Anthony was senseless to have said what he did and in the way that he did.

Only now I understand I was in fact in autopoiesis. I was languaging and emotioning (Maturana, 1980) everytime I told the same story again and again, constantly searching for both verification about my own interpretation and an opening or a place for a different interpretation in my understanding. I had certainly gone through a moment of perturbation, and now I was in a state of total disequilibrium. To regain my equilibrium I had to talk about the incident and complete the cycle of autopoiesis or self-regeneration.

From all of that I learned that my answer was an instant defensive reaction. It is similar to the situation in which you complain about your mom, you say she is this and that, and when your partner decides to point out one of her flaws you get angry because after all, she is your mom and you are the only person who can point out her flaws because nobody knows her better than you do.

At the moment I wanted to make sure that everyone understood I did not agree with Anthony's opinion, but was he totally wrong? No, he was not. I have to admit. Now. However, that does not make him right either. I learned that Anthony had made a generalization based on a stereotype he might have heard or seen about the Police in Brazil. Maybe he had watched the movie "Elite Squad", which shows corruption is a reality inside the Brazilian Police. Unfortunately Brazil is known for its corruption. As Meyer (2013) declares, "a search for manifestations of foreigners about what they think of the Brazilian culture and/or identity is very revealing of how the negative stereotypes outnumber the positive ones on the way Brazil is perceived outside."3 (Meyer, 2013, p. 23)

Although I still think Anthony was unwise to express his stereotypical idea so bluntly, I now understand that instead of feeling so offended I should have used that situation as a teaching opportunity because, as Clouet (2006) defends, "it is the teacher's role to help learners become aware of these stereotypical images, through discussions and critical examinations of them in the classroom" (Clouet, 2006, p. 57). Further, I should have inquired as to how such a situation might have been handled in Jamaica. Perhaps Anthony was using his knowledge from Jamaica and simply applying it to the Brazilian context?

These types of incidents are common in Portuguese (or other) second language classes. Students come to our classes not only to learn the language, but also the culture. They deserve a forum in which they can express their perceptions honestly and openly and we, as their teachers, must learn how to use their perceptions as course material and not personal or cultural attacks on what we hold so dear. Thus we must be emotionally

\footnotetext{
${ }^{2}$ A Brazilian movie, called "Tropa de Elite" in Portuguese.

${ }^{3}$ My translation from Portuguese.
} 
prepared not to take offense, but rather to dig deeper into the understandings of students, as well as our own, and transform these moments into ones of intercultural competencies. For students such observations are reflections of their habitus, be they from films, media or the stereotypes that float about the planet. Our challenge as teachers is to help students question their source. In retrospect, on that day I might have had a different conversation with Anthony. Perhaps had I asked "why do you think that would work?" I might have learned that such actions are equally known in Jamaica? Or that others have had such experiences and they did not work? Or that some other student or even all of them thought the same way Anthony did? This would have been a great chance for all of us to reflect upon our own perceptions and opinions about others and their cultures. This incident was definitely a great learning experience for me, and I am glad I will have many other chances to deal with the situation in a more productive and constructive way with other students that will come. Our SL classrooms offer opportunities to discuss with one another - students and teachers - our cultural similarities and differences and begin to explore the whole habitus that inhabits our minds and co-create a small culture (Holliday, 1999).

References:

CLOUET, R. "Between one's culture and the target culture: the language teacher as intercultural mediator". Porta Linguarum, 5, 2006, p.53-62.

HOLliDAY, A. "Small Cultures". Applied Linguistics 20/2: 237-264. Oxford University Press, 1999.

MATURANA, H. R. \& VARELA, F. J., Autopoiesis and Cognition: The Realization of the Living, Vol. 42 of Boston Studies in the Philosophy of Science, D. Reidel Publishing Company, Dordrecht, Holland. With a preface to 'Autopoiesis' by Stafford Beer. Series editors: Robert S. Cohen and Marx W. Wartofsky, 1980.

MEYER, R. M. "Para o bem ou para o mal: a construção de identidade pelo falante de PL2E a partir de estereótipos de brasilidade - uma questão intercultural." Português para Estrangeiros: Questões Interculturais, 2013, p. 13-34. 